Article

\title{
The Effect of Co-Additives (Biochar and FGD Gypsum) on Ammonia Volatilization during the Composting of Livestock Waste
}

\author{
Andi Febrisiantosa ${ }^{1,2}$ (D), Balasubramani Ravindran ${ }^{3}$ and Hong L. Choi ${ }^{1, *}$ \\ 1 Department of Agricultural Biotechnology, Research Institute for Agricultural and Life Science, \\ Seoul National University, Seoul 151-742, Korea; andi82@snu.ac.kr or andi.febrisiantosa@gmail.com \\ 2 Research Unit for Natural Product Technology (BPTBA) - Indonesian Institute of Sciences (LIPI), \\ Yogyakarta 55861, Indonesia \\ 3 Department of Environmental Energy and Engineering, Kyonggi University, Youngtong-Gu, \\ Suwon 16227, Korea; kalamravi@gmail.com or ravindran@kyonggi.ac.kr \\ * Correspondence: ulsoo8@snu.ac.kr or aebe4801@gmail.com; Tel.: +82-2-880-4808
}

Received: 5 February 2018; Accepted: 8 March 2018; Published: 13 March 2018

\begin{abstract}
The effectiveness of co-additives for improving livestock waste composting (reduction of air pollution and conservation of nutrients) was investigated. Biochar and Flue gas desulphurization gypsum (FGD gypsum) were used to supplement the composting of a mixture of slaughter waste, swine slurry, and sawdust. Different compositions of additives $(0 \%$ or $5 \%$ each, $10 \%$ biochar or FGD gypsum) were tested in triplicate on the laboratory scale. In addition, the effects of two different aeration schemes (continuous and intermittent) were also investigated. Ammonia volatilization, physicochemical characteristics, and compost maturity indices were investigated. The results indicated that the use of the co-additive (Biochar and FGD gypsum) during composting of livestock waste led to a reduction of ammonia volatilization by $26-59 \%$ and to a $6.7-7.9$-fold increase of nitrate accumulation. The total ammonia volatilization of intermittent aeration treatment was lower than that of continuous aeration using co-additives treatment. It was concluded that co-additives (biochar and FGD gypsum) might be utilized in livestock waste composting to reduce ammonia volatilization and improve nutrient conservation.
\end{abstract}

Keywords: livestock waste; composting additives combination; ammonia; volatilization

\section{Introduction}

The livestock sector globally is highly dynamic and is organized in long market chains that employ at least 1.3 billion people worldwide and directly support the livelihoods of 600 million poor smallholder farmers in the developing world [1]. However, the waste from livestock industrial activities (for example manure, slaughter waste), is the major source of negative environmental impacts (that is, the release of greenhouse gases or excess nutrients, salt accumulation, growth of pathogenic microorganisms, odor, and so on), which are capable of influencing both humans and animals $[2,3]$. Composting is an effective technology for treatment and disposal of livestock and agricultural waste. This is because it can be converted to sanitary and marketable organic fertilizer $[4,5]$. The stabilization process during composting kills most parasites, pathogens, and viruses contained in the livestock waste $[6,7]$.

Nevertheless, the process of aerobic composting can cause problems. Several chemical compounds (for example, hydrogen sulfide $\left(\mathrm{H}_{2} \mathrm{~S}\right)$, trimethylamine (TMA), ammonia $\left(\mathrm{NH}_{3}\right)$, 2-pentanone, 1-propanol-2-methyl, dimethyl sulfide, dimethyl disulfide, dimethyl trisulphide, and acetophenone) were identified as the main potential odor contributors from composting, which were correlated with 
both the aeration rate and the ratio of bulking agent to waste during composting [8,9]. Among the potential odor compounds, ammonia $\left(\mathrm{NH}_{3}\right)$ is a major component that causes odors nuisance and toxicity to humans and plants [10]. Nitrogen losses that occurred during composting resulted in the emission of ammonia $\left(\mathrm{NH}_{3}\right)$ gas (ammonia volatilization) accounted for $24-33 \%$ of the initial $\mathrm{N}$ in household waste [11], 46.8-77.4\% of the initial $\mathrm{N}$ of a mixture of straw and manure [12], $62 \%$ of the initial $\mathrm{N}$ was during composting of poultry layer manure [13], and $24-64 \%$ of the nitrogen was in organic waste [14]. The volatilization of ammonia deteriorating both human health and the environment would reduce the fertilizer value of the organic waste. Barrington et al. [15] reported that carbon availability, bulking agent, particle size, moisture content, and aeration regime are the factors that determine whether composting results in $\mathrm{N}$ volatilization as odor or $\mathrm{N}$ immobilization into organic components. The odor emission rate was correlated with both the aeration rate and the ratio of bulking agent to waste when composting [8].

The utilization of chemical and biological additives to mitigate ammonia volatilization and nitrogen loss during the composting process has been extensively studied. These additives have included wood fly ash, lime, phosphor-gypsum, polyethylene glycol, jaggery [16], zeolite [17], bentonite [18], superphosphate [19], and microbial inoculants [20]. Among these additives, biochar was popular to be amended in the composting mixture. Biochar is a carbon rich material produced by the thermal decomposition of biomass, was effective for reducing volatilization of ammonia during the composting of a mixture of sewage sludge and wood chips [21]. The faster decomposition process in the bio-oxidative phase led to lower greenhouse gas emissions being observed when biochar was added at the beginning of the composting process [22,23]. Reduction in readily available $\mathrm{P}$ was observed when biochar was applied during compost storage [22]. Biochar addition at 3\% could reduce the composting time by $20 \%$ [24]. As a composting additive, biochar favored microbial activity [25,26]. Jindo et al. [26] reported a higher diversity of fungi in biochar-amended compost. Biochar materials strongly sorb polycyclic aromatic hydrocarbons (PAHs) and are thus characterized by very high sorption coefficients $\left(\mathrm{K}_{\mathrm{D}}\right)$ for PAHs [27].

It was also reported that the $\mathrm{N}$ loss was mitigated by adding FGD gypsum to composting materials [28,29]. Flue gas desulphurization gypsum (FGD gypsum) is a by-product of wet gas desulphurization in coal-fired power stations and generally has a high purity, low heavy metal content, and is rich in essential mineral nutrients for plants such as S, Si and Ca [30,31]. The volatilization of ammonia and $\mathrm{N}$ loss were reduced by combining organic $\mathrm{N}$-rich organic waste with FGD gypsum during the composting process [29]. The nitrogen compounds of humic substance in compost with FGD gypsum was higher than that in compost without FGD gypsum [30]. Gypsum has been known as an effective product used in the remediation of sodic soils, by greatly reducing the exchangeable $\mathrm{Na}$, $\mathrm{K}$, and $\mathrm{Mg}$ cation concentrations in the sodic soils [32,33]. Approximately $1-2 \mathrm{wt} \%$ of FGD gypsum was used to reclaim the sodic soil which resulted in no obvious heavy metal contamination [31]. Guo et al. [30] suggested adding 10\% FGD gypsum to compost material to reduce nitrogen loss during composting. Information is still limited on the co-additive means of more than one additive supplemented together when applied with different aeration methods during the composting of livestock waste. Accordingly, the objectives of this research were to investigate the effect of co-additives (FGD gypsum and biochar) and the different aeration schemes (Continuous and Intermittent) on the performance of livestock waste composting and on its product.

\section{Materials and Methods}

\subsection{Feedstock Preparation and Experimental Setup}

The mixture of swine slurry and slaughter waste were utilized as livestock waste in this study. Mixtures of swine slurry and slaughter waste for composting trials were not commonly applied yet in South Korea. The swine slurry was obtained from the swine farm station of Seoul National University. The slaughter waste was obtained from a local slaughter house in Yeongcheon City (North Gyeongsang 
Province, Korea). These livestock wastes functioned as the main substrate for the composting process. Sawdust was utilized as a bulking agent and was obtained from the local municipality. The Biochar was obtained from the local producer in Gyeonggi province, South Korea. It was produced from combination of hardwood $(80 \%)$ and softwood $(20 \%)$ by the pyrolysis process at $550{ }^{\circ} \mathrm{C}$. FGD gypsum was obtained from the KEPCO coal-fired power plant of South Korea. Prior to composting, the physicochemical properties of the raw materials were given in Table 1.

Table 1. Properties of raw materials used for composting experiment.

\begin{tabular}{cccccc}
\hline & Swine Slurry & Slaughter Waste & Sawdust & Biochar & FGD Gypsum \\
\hline $\mathrm{pH}$ & 8.09 & 6.23 & 7.59 & 10.99 & 8.54 \\
$\mathrm{EC}(\mu \mathrm{S} / \mathrm{cm})$ & 22.25 & 6.85 & 0.15 & 0.73 & 2.69 \\
$\mathrm{BD}(\mathrm{g} / \mathrm{L})$ & 1059.75 & 1133.92 & 243.57 & 515.29 & 703.33 \\
$\mathrm{TS}(\%)$ & 6.27 & 26.11 & 81.49 & 90.35 & 77.75 \\
VS $(\% \mathrm{TS})$ & 72.15 & 94.91 & 98.99 & 65.90 & 3.04 \\
Ash (\%) & 27.85 & 5.09 & 0.94 & 34.10 & 96.06 \\
TOC (\%TS) & 41.85 & 55.05 & 57.42 & 38.23 & 2.41 \\
TKN (\%TS) & 6.74 & 6.26 & 0.37 & 0.36 & n.d \\
C/N & 6.21 & 8.79 & 155.18 & 105.02 & n.d \\
\hline
\end{tabular}

$\mathrm{EC}$ = Electrical conductivity; $\mathrm{BD}$ = Bulk density; $\mathrm{TS}$ = Total solid; $\mathrm{VS}$ = Volatile solid; TOC = Total organic carbon; $\mathrm{TKN}=$ Total Kjeldahl Nitrogen; $\mathrm{C} / \mathrm{N}=\mathrm{C} / \mathrm{N}$ ratio.

The experiment was prepared with eight different sets of composting mixtures with different co-additive combinations and aeration schemes labelled CC, BC, FG, FB, CC-I, BC-I, FG-I, and FB-I respectively (Table 2). Mixed raw materials of an amount of $5 \mathrm{~kg}$ were composted in $15 \mathrm{~L}$ cylindrical laboratory scale composter reactors (height $30 \mathrm{~cm} \times$ inner diameter $25 \mathrm{~cm}$ ) covered with polyurethane insulation material to prevent heat loss (Figure 1). The experiment was conducted for 28 days. The compost pile was stirred on Day 7, 14, and 21. Samples of approximately $150 \mathrm{~g}$ each were collected just after the materials were stirred; then were kept at $4{ }^{\circ} \mathrm{C}$ for later physicochemical analysis. The aeration rate of $0.75 \mathrm{~L} / \mathrm{min} \cdot \mathrm{kg}$ VS was set to keep the oxygen concentration above $15 \%$, as suggested by References [33] and [34]. For the intermittent aeration, the air pump was left off for $135 \mathrm{~min}$. then a timer switched on the high flow air pump for $15 \mathrm{~min}$. to provide air at about $0.75 \mathrm{~L} / \mathrm{min} \cdot \mathrm{kg}$ VS. The composition ratio of raw material was considered to reach the initial moisture content of about $55-60 \%$ as most suitable condition for the composting process.

Table 2. Feedstock composition ratio of treatment compost.

\begin{tabular}{ccccccc}
\hline \multirow{2}{*}{ Treatment } & \multicolumn{2}{c}{ Feedstock Ratio (\% Wet Weight) } & \multicolumn{2}{c}{$\begin{array}{c}\text { Additive (\% Raw } \\
\text { Feedstock on Wet Weight) }\end{array}$} & \multirow{2}{*}{ Aeration } \\
\cline { 2 - 5 } & $\begin{array}{c}\text { Slaughter } \\
\text { Waste (\%) }\end{array}$ & $\begin{array}{c}\text { Swine } \\
\text { Slurry (\%) }\end{array}$ & $\begin{array}{c}\text { Sawdust } \\
\mathbf{( \% )}\end{array}$ & $\begin{array}{c}\text { FGD Gypsum } \\
\mathbf{( \% )}\end{array}$ & $\begin{array}{c}\text { Biochar } \\
\mathbf{( \% )}\end{array}$ & \\
\hline CC & 41.7 & 16.7 & 41.6 & - & - & continuous \\
BC & 41.7 & 16.7 & 41.6 & - & 10 & continuous \\
FG & 41.7 & 16.7 & 41.6 & 10 & - & continuous \\
FB & 41.7 & 16.7 & 41.6 & 5 & 5 & continuous \\
CC-I & 41.7 & 16.7 & 41.6 & - & - & intermittent \\
BC-I & 41.7 & 16.7 & 41.6 & - & 10 & intermittent \\
FG-I & 41.7 & 16.7 & 41.6 & 10 & - & intermittent \\
FB-I & 41.7 & 16.7 & 41.6 & 5 & 5 & intermittent \\
\hline
\end{tabular}




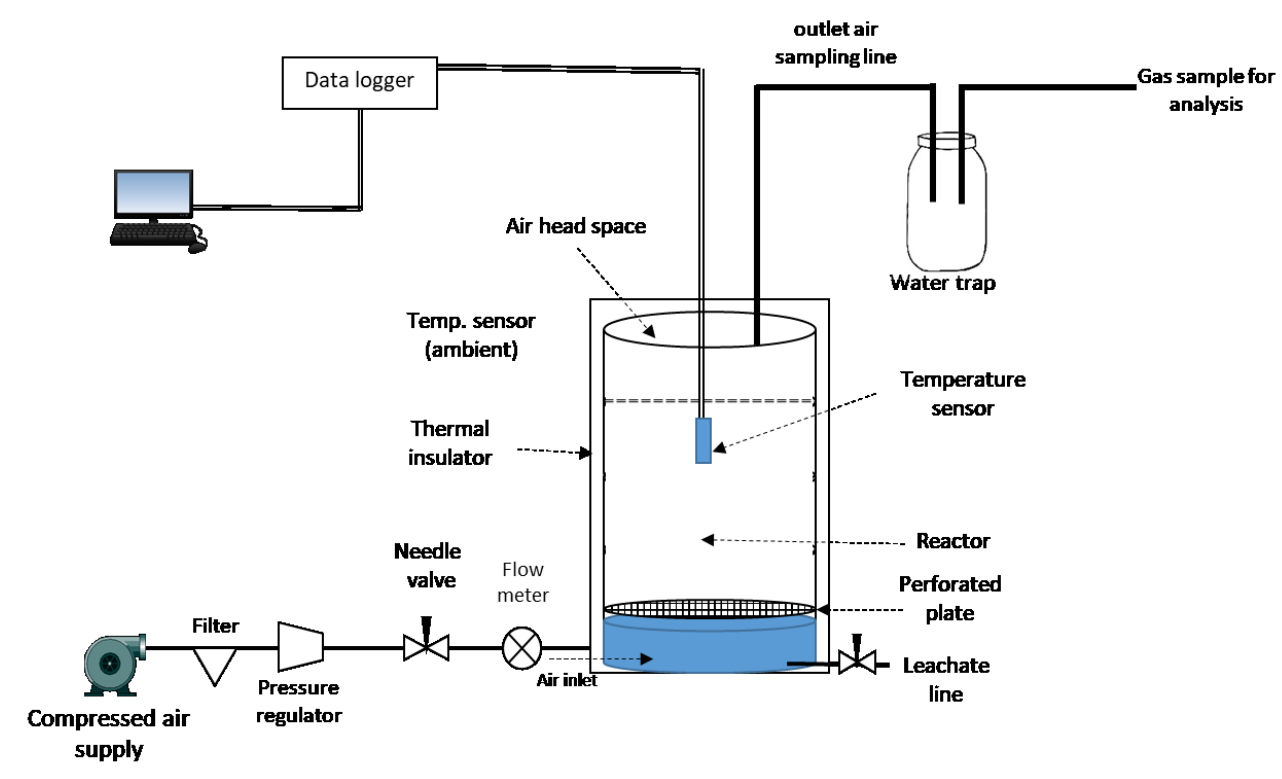

Figure 1. Reactor for composting experiment.

\subsection{Physicochemical Parameter Analysis}

Samples of the raw materials and treatment mixtures were air dried, ground up into small particles using porcelain mortar, and passed through a 2-mm sieve. The sieve samples were analyzed for physicochemical properties. The physicochemical characteristics of samples and raw materials were analyzed using methods on dry weight basis [35]. The moisture content was determined by drying fresh samples at $105^{\circ} \mathrm{C}$ until the mass loss in $24 \mathrm{~h}$ was less than $0.5 \%$ relative to the previous day. Volatile solid was measured by dry combustion of dried samples $\left(550{ }^{\circ} \mathrm{C}\right.$ for $4 \mathrm{~h}$ ). The $\mathrm{pH}$ and electrical conductivity (EC) were determined using a pH meter (Inolab, WTW, GmbH, Weilheim, Germany) and an EC214 conductivity meter (Hanna Instruments, Ltd., Sarmeola di aarubano, Italy) respectively. The sample was suspended in distilled water in a ratio of 1:10 $(w / v)$. This suspension was shaken in a mechanical shaker at $230 \mathrm{rpm}$ for $30 \mathrm{~min}$ and allowed to stand for an hour prior to $\mathrm{pH}$ and EC measurement. Bulk density of compost material was defined as its weight per unit volume according to Thompson [36]. The Kjeldahl Nitrogen (TKN) content was determined according to the Kjeldahl digestion method [37]. The TOC was determined by the Walkey Black method [38]. C/N ratio was estimated by divided the TOC to the TKN. Inorganic nitrogen $\mathrm{NH}_{4}^{+}, \mathrm{NO}_{3}^{-}$and $\mathrm{NO}_{2}^{-}$were extracted using $2 \mathrm{~mol} / \mathrm{L} \mathrm{KCL} \mathrm{(10:1} \mathrm{V/m),} \mathrm{and} \mathrm{then} \mathrm{analyzed} \mathrm{using} \mathrm{DR} 5000 \mathrm{UV}$-Vis spectrophotometry (Hach Co., Loveland, CO, USA). The ambient temperature and compost temperature in the center of the composting mixture were recorded hourly by a temperature sensor and data logger (T\&D recorder TR52i, Shinagawa, Japan). $\mathrm{NH}_{3}$ was measured by washing bottle according to the method presented by Ren et al. [39]. Ammonia gas released during composting was captured in boric acid and was determined by the spectrophotometric method (Hach Co., Loveland, CO, USA).

The phytotoxicity was evaluated according to the method proposed by Sellami et al. [40] with modification. The Germination Index (GI) was determined by extracting $20 \mathrm{~g}$ (dry weight) of compost with $200 \mathrm{~mL}$ of distilled water, stirring for $2 \mathrm{~h}$, and then centrifuging at $9000 \mathrm{r} / \mathrm{min}$. Ten Raphanus sativus (white radish) seeds were evenly distributed on filter paper in Petri dishes (10 cm diameter) and moistened with $5 \mathrm{~mL}$ of compost extract. Three replicate dishes for each sample were incubated at $25^{\circ} \mathrm{C}$ for three days. The number of seeds that germinated was recorded. As a control, $5 \mathrm{~mL}$ of distilled water was used to replace the compost extract. The GI was calculated according to the Equation (1):

$$
\text { GI }(\%)=\frac{\text { seed germination } \times \text { root length of treatment }}{\text { seed germination } \times \text { root length of control }} \times 100 \%
$$


Elemental analysis (that is, $\mathrm{P}, \mathrm{K}, \mathrm{Na}, \mathrm{Ca}, \mathrm{Mg}, \mathrm{Fe}, \mathrm{Mn}, \mathrm{Cu}, \mathrm{Zn}$, and $\mathrm{S}$ ) of the samples were performed according to standard nitric acid-hydrochloric acid digestion (3030 F, APHA) [35] and using inductively coupled plasma (ICP) atomic emission spectroscopy (AES) (ICPS-7510; Shimadzu Corp., Kyoto, Japan).

\subsection{Statistical Analysis}

The physicochemical parameter data reported in this study were analyzed by ANOVA using the statistical package SPSS 21 . The average values of the quantitative factors under evaluation were compared by means of Tukey's test.

\section{Results and Discussion}

\subsection{The Effect on Temperature, $p H$, and EC}

The temperature change during composting is associated with many biological reactions that take place [41]. The increase of temperature has been widely reported to correlate with microbial activities [22,23]. The composting temperature during this experiment is shown in Figure 2A,B. Initially, the temperature in the piles was about $23^{\circ} \mathrm{C}$. On the first day, the temperature increased rapidly in all treatments. The temperature remained above $55^{\circ} \mathrm{C}$ for $1-2$ days. According to the temperature profiles, the compost with the continuous aeration scheme reached a higher temperature than that of the compost with intermittent aeration. Composting with continuous aeration reached a temperature of $55-60{ }^{\circ} \mathrm{C}$ for two consecutive days, while the temperature in the intermittently aerated compost reached $50-55{ }^{\circ} \mathrm{C}$ for almost three consecutive days. The composting temperature with intermittent aeration was lower than that with continuous aeration, likely because the oxygen supplied was not constantly adequate for complete bio oxidation [42,43]. The longer thermophilic phase that occurred with intermittent aeration composting was likely a result of the slower degradation of partially decomposed materials transferred from the anaerobic areas to aerobic areas, as explained by Jiang et al. [44]. The fact that the composting temperature remained above $55{ }^{\circ} \mathrm{C}$ for three days was adequate to provide standard sterilization of the compost [45]. This phase was followed by a mesophilic phase. This condition corresponded to a typical composting temperature profile at the laboratory scale. According to the temperature profiles, the FGD gypsum additive supplementation did not disturb the composting process. This result was in accordance with the results of Li et al. [18] who reported that composting supplemented with bentonite did not show any stimulatory or inhibitory effects on the composting temperature profile. In this study, the highest temperature was reached in the biochar additive treatment. López-Cano [46] reported that the addition of biochar favored activation of the composting process.

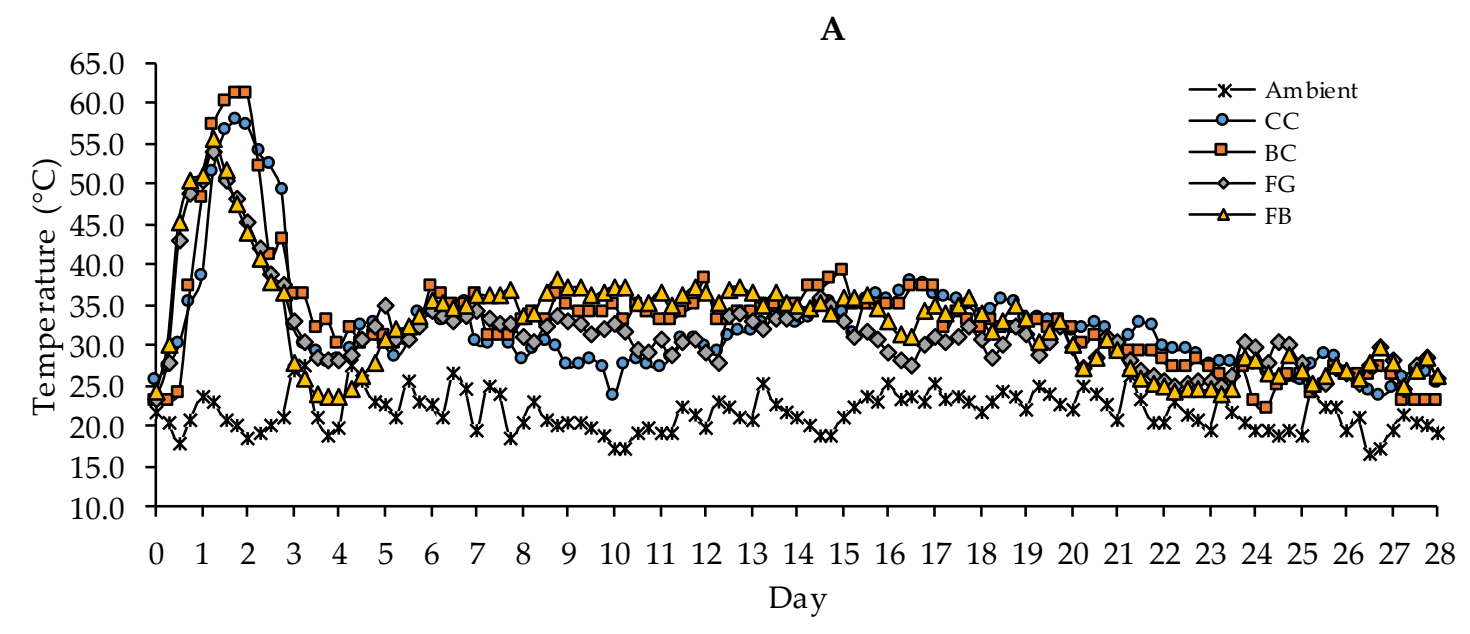

Figure 2. Cont. 


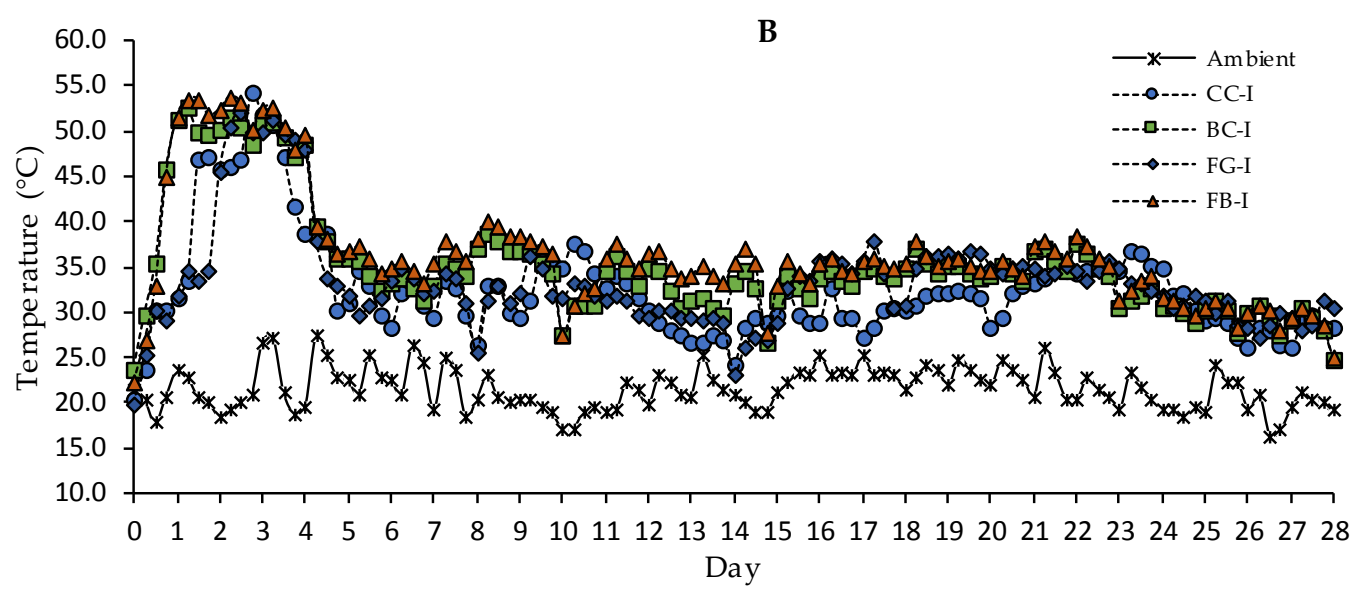

C
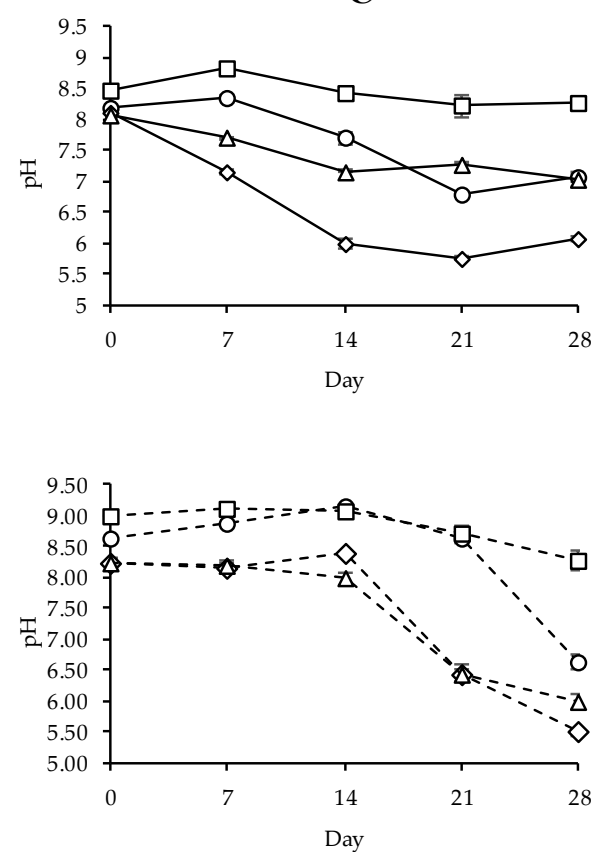

D
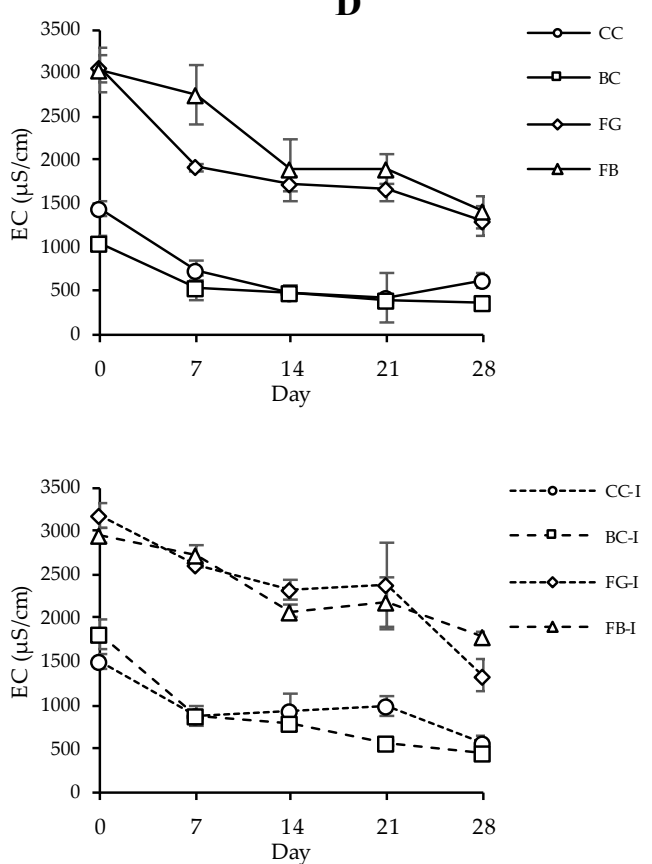

Figure 2. Temperature ((A) Continuous; (B) Intermittent); $\mathrm{pH}(\mathbf{C})$ and EC (D) profiles throughout composting process in eight treatments.

The $\mathrm{pH}$ change throughout the composting process is shown in Figure $2 \mathrm{C}$. The $\mathrm{pH}$ of all treatments showed gradually decrease. The decline of $\mathrm{pH}$ is linked to natural acidification as a result of nitrification during the composting process [47]. The co-additives of FGD gypsum and biochar had a significant effect on the compost $\mathrm{pH}(p<0.05)$. FGD gypsum supplementation had a greater influence on lowering $\mathrm{pH}$, which was shown by the $\mathrm{pH}$ decline from $8.10-8.60$ to $5.45-6.93$ within 28 days of composting. The gradual decline of the $\mathrm{pH}$ was likely due to the formation of low-molecular-weight organic acids and $\mathrm{CO}_{2}$ during the decomposition of organic matter, volatilization of ammonia, and nitrification during the composting process $[26,28]$. The $\mathrm{pH}$ decrease was also attributed to the replacement of $\mathrm{Na}^{+}$by Ca ${ }^{2+}$ from the FGD gypsum, by which the reaction $\mathrm{CO}_{3}^{2-}+\mathrm{HCO}_{3}^{2-}$ generated deposits of $\mathrm{CaCO}_{3}$ [48]. The $\mathrm{pH}$ of the compost supplemented with biochar only remained higher. This was probably attributable to the initially high $\mathrm{pH}$. In addition, the rate of ammonia released due to ammonification was higher in this treatment. The $\mathrm{pH}$ increase was a result of ammonification and mineralization during composting [42]. The different aeration schemes resulted in no significant difference on the compost $\mathrm{pH}$ in this study. 
Soluble salt contents were estimated through electrical conductivity (EC). The EC values throughout the composting process are presented in Figure 2D. The initial EC of the treatment with only FGD gypsum was higher. Supplementation with FGD gypsum significantly increased the initial EC of the compost substrate and was likely due to the contribution of the high mineral concentration in FGD gypsum. Possible phytotoxic effects could result in compost with high EC values, which indicates high salinity in the composting product. In this study, we observed that EC values decreased with the composting time in all treatments. The decrease of EC could be caused by the volatilization of ammonia and the precipitation of mineral salts during the composting process [42]. The results observed in this study suggested that the FGD gypsum supplementation did not have a negative effect on the composting process.

\subsection{The Effect on Ammonia Volatilization}

The results of ammonia emission throughout composting in all treatments are shown in Figure 3. Compared with the control, the cumulative ammonia emitted from composting with FGD gypsum was significantly less with both the continuous or intermittent aeration scheme. Biochar addition resulted in higher ammonia emission than did the addition of FGD gypsum. Intermittent aeration resulted in lower cumulative ammonia emission. In composting with continuous aeration, $90 \%$ of the ammonia was emitted during the first ten days after commencement of composting whereas with intermittent aeration, the ammonia emission was distributed over 20 days after the composting start. The higher ammonia emission with the biochar additive could be attributed to higher $\mathrm{pH}$ and temperature. Tiquia and Tam [49] reported that the loss of $\mathrm{N}_{\text {by }} \mathrm{NH}_{3}$ volatilization was significant at $\mathrm{pH}$ levels above 7.0 and higher temperatures $\left(>40{ }^{\circ} \mathrm{C}\right)$ [49]. Furthermore, at a higher $\mathrm{pH}$, non-volatile ammonia ions were converted to the volatile ammonia form [50]. The highest $\mathrm{NH}_{3}$ volatilization rates in the present study occurred at $50^{\circ} \mathrm{C}$. It was likely because the high temperature affects ammonia volatilization by inhibiting the nitrification process [51].

The reduction of ammonia volatilization in this experiment could be attributed to a lower $\mathrm{pH}$ and to ammonia absorption affected by the addition of FGD gypsum. Jeong and Kim [52] found that using amendments such as bauxite residues or biodegradable plastics could control compost $\mathrm{pH}$. Guo et al. [30] reported that FGD gypsum has the ability to absorb ammonia. In addition, gypsum addition converts the ammonium carbonate to ammonium sulfate along with the formation of calcium carbonate [30]. The $\mathrm{N}$ in ammonium carbonate is much more apt to be lost as ammonia than when it is in the form of ammonium sulfate [29]. We observed that by FGD gypsum supplementation, $\mathrm{NH}_{3}$ volatilization could be reduced by $75.46 \%$ with continuous aeration, in comparison to the control. Co-additive supplementation with FGD gypsum and biochar reduced the ammonia volatilization by $58.93 \%$ with continuous aeration, in comparison to the control. Supplementation by biochar increased the ammonia volatilization by about $22.17 \%$ in comparison to that of the control. By intermittent aeration, FGD gypsum alone and co-additive supplementation reduced the ammonia volatilization by $52.64 \%$ and $25.87 \%$, respectively. These results were in accordance with the results of Koenig et al. [51] who demonstrated that aluminum sulfate; chloride salts of aluminum, calcium and magnesium; gypsum; and surface-applied sodium bisulfate reduced the $\mathrm{NH}_{3}$ volatilization by $0-87 \%$, depending on the rate and intervals of incubation. We observed in the present study that the lower $\mathrm{NH}_{3}$ volatilization rates mostly related to the reduction in the $\mathrm{pH}$ of the substrate. The results of the present study show that ammonia volatilization after biochar treatment was significantly higher than that of other treatments. Biochar supplementation increased ammonia volatilization by $63.24 \%$ in comparison to that of the control. These results contrast with earlier findings that suggested that co-composting with biochar might reduce ammonia emission and increase nitrification [53]. The possible explanation of this result is that the high initial $\mathrm{pH}$ and temperature of the composting substrate induced the higher volatilization of ammonia. Schomberg et al. [54] found that biochar and biochar mixed with ash have the potential to raise the substrate $\mathrm{pH}$. Mandal et al. [55] explained the significant linear relationship between the soil $\mathrm{pH}$ values and the cumulative $\mathrm{NH}_{3}$ volatilization from soils. Ammonia volatilization 
is favored at alkaline $\mathrm{pH}$ and when a high concentration of $\mathrm{NH}_{4}^{+}$is present. When $\mathrm{NH}_{4}^{+}$and $\mathrm{OH}^{-}$are present in the substrate, the $\mathrm{OH}^{-}$ions readily react with $\mathrm{NH}_{4}^{+}$ions, thereby resulting in the release of $\mathrm{NH}_{3}$ gas [56], as described in Equation (2).

$$
\mathrm{NH}_{4}^{+}+\mathrm{OH}^{-} \rightarrow \mathrm{NH}_{3} \uparrow+\mathrm{H}_{2} \mathrm{O}
$$

Schomberg et al. [38] demonstrated that $\mathrm{NH}_{3}$ volatilization increased when biochar with a high $\mathrm{pH}$ was applied. This was because at high $\mathrm{pH}$, the ammonification process accelerated, thereby increasing the $\mathrm{NH}_{3}$ volatilization. A corresponding increase in $\mathrm{NH}_{3}$ volatilization was observed as a result of the higher $\mathrm{pH}$ (increased $\mathrm{OH}^{-}$concentration) during the first seven days of composting unless treatment with FGD gypsum occurred along with continuous aeration. The high ammonification process seems to have stopped after the first seven days of composting, and the nitrification process started with a corresponding decline in $\mathrm{NH}_{3}$ volatilization and compost $\mathrm{pH}$. The decline of the compost $\mathrm{pH}$ could be attributed to the nitrification reaction. $\mathrm{NH}_{4}^{+}$ions oxidized directly to $\mathrm{NO}_{3}^{-}$ions and released $\mathrm{H}^{+}$ions, which subsequently reduced $\mathrm{NH}_{3}$ volatilization. The slow mineralization of $\mathrm{N}$ was reported to be one possible reason for the low $\mathrm{NH}_{3}$ volatilization [55]. The explanation of low $\mathrm{NH}_{3}$ and high $\mathrm{NH}_{4}^{+}$with FGD gypsum treatment could be that acidic surfaces (low $\mathrm{pH}$ ) can protonate $\mathrm{NH}_{3}$ gas to form $\mathrm{NH}_{4}^{+}$ions, as in Equation (3).

$$
\mathrm{NH}_{3}+\mathrm{H}^{+} \rightarrow \mathrm{NH}_{4}^{+}
$$

The treatment with intermittent aeration shows many peaks of ammonia emission even after 14 days composting (Figure 3B). According to Tiquia and Tam [49] and Liang et al. [57], the occurrence of several $\mathrm{NH}_{3}$ emissions peaks could be explained in three ways. (1) Part of the organic $\mathrm{N}$ was first degraded to some simple $\mathrm{N}$-containing compounds and stored in the compost. These compounds were mineralized after biodegradation slowed down; (2) A slowly degradable fraction with high content of biodegradable $\mathrm{N}$ was mineralized; (3) $\mathrm{NH}_{4}^{+}$released from ammonification at the beginning of the treatment was first immobilized in the biomass; then, the remineralization of the biomass was responsible for the next peak of $\mathrm{NH}_{3}$ emissions. Furthermore, it was explained that during incomplete nitrification, under the effect of ammonia monooxygenase, $\mathrm{NH}_{3}$ is oxidized sequentially to hydroxylamine $\left(\mathrm{NH}_{2} \mathrm{OH}\right)$ and nitroxyl $(\mathrm{NOH})$ by hydroxylamine oxidoreductase, which can be converted to $\mathrm{N}_{2} \mathrm{O}$ [58]. Koenig et al. [51] also reported that the increase of $\mathrm{NH}_{3}$ volatilization could be due to the physical effects from changes in materials and pore-space causing enhanced ventilation, as well as of improved aerobic decomposition during composting. In later work, de Guardia et al. [59] demonstrated that $\mathrm{NH}_{3}$ emissions were much higher at higher aeration rates and suggested the importance of the mineralization of organic $\mathrm{N}$.

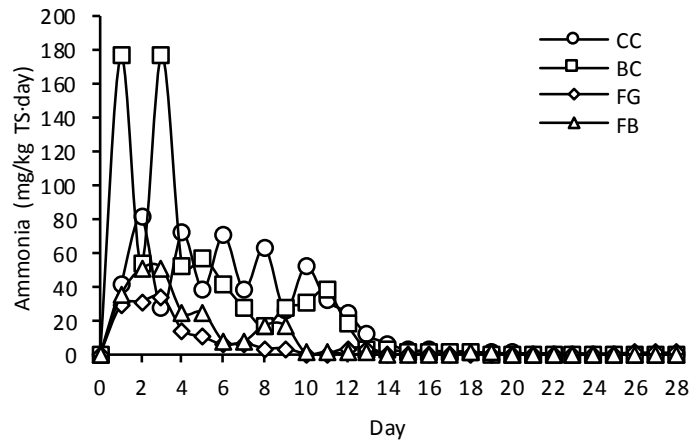

(A)

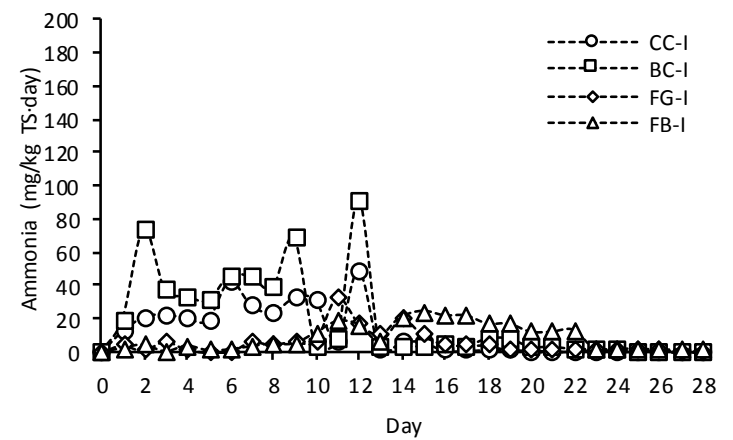

(B)

Figure 3. Cont. 


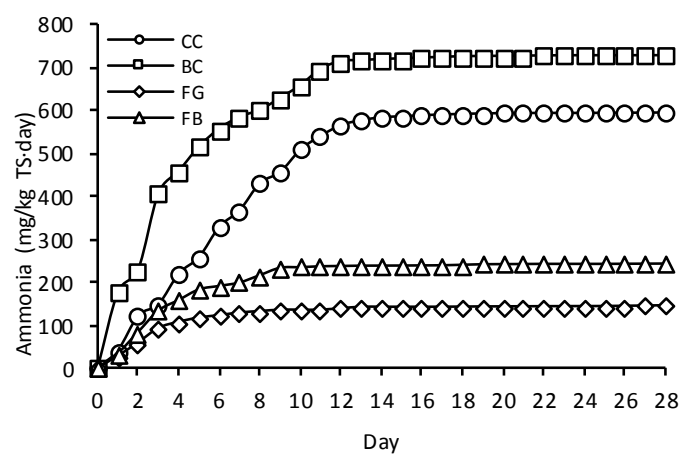

(C)

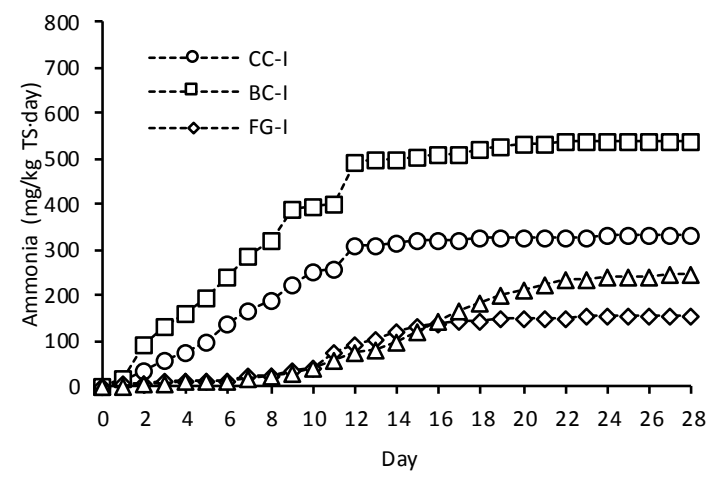

(D)

Figure 3. Daily and cumulative ammonia production throughout composting process (A) Daily, continuous aeration; (B) Daily, intermittent aeration; (C) Cumulative, continuous aeration; (D) Cumulative, intermittent aeration.

\subsection{The Effects on Organic Matter, $\mathrm{TKN}, \mathrm{C} / \mathrm{N}, \mathrm{NH}_{4}^{+}, \mathrm{NO}_{3}^{-}+\mathrm{NO}_{2}^{-}, \mathrm{NH}_{4}^{+} / \mathrm{NO}_{3}^{-}$}

The effects of treatments on TOC throughout the composting are shown in Figure 4A. TOC content slightly decreased in all treatments. There was no significant effect from the aeration schemes on the decrease of TOC during the composting in this experiment, however by co-additive treatment, the decrease in TOC was $4.98 \%$ during the 28 days composting. This could be due to the ability of FGD gypsum and biochar to increase the porosity of the compost substrate. Li et al. [18] reported that the decomposition of organic matter was enhanced by the addition of bentonite, clinoptilolite, and zeolite. Gao et al. [42] reported a decrease of $15.4 \%$ in 60 days of composting chicken manure. Tiquia and Tam [49] reported $9 \%$ organic matter loss during 120 days of chicken manure composting.

The variation of TKN during the composting process is presented in Figure 4B. The TKN content gradually increased under all treatments. The result in the present study was in accordance with Li et al. [18] who found that the TKN content improved by the addition of bentonite during swine manure composting. The TKN increase can be attributed to a concentration effect as a consequence of the degradation of organic compounds because composting biomass is reduced faster than nitrogen [47]. The loss of TKN during the first week of composting was likely because of the loss of ammonia due to the volatilization at a relatively high temperature. TKN increased the most in co-additive treatment ( $5 \%$ FGD gypsum and 5\% biochar). This result was likely associated with the additive combination speeding up the degradation rate during the composting process. The large specific surface area of the biochar was more favorable for microbial attachment. In addition, the porosity of the biochar made air and moisture available to the compost material, which is favorable for the decomposition process in composting [47]. On the other hand, FGD gypsum supplied more mineral nutrient sources for microbial growth, which accelerated the decomposition of organic matter.

The mineralization of organic matter during composting led to the gradual decrease of the $\mathrm{C} / \mathrm{N}$ ratio (presented in Figure $4 \mathrm{C}$ ). The $\mathrm{C} / \mathrm{N}$ ratio of the control and biochar treatment slightly increased in the first week of composting; then gradually decreased as the composting progressed. The slight increase of the $\mathrm{C} / \mathrm{N}$ ratio in the first week of the composting process could be due to vigorous ammonia volatilization [49]. Organic matter degradation and nitrogen compound mineralization then responded to the reduction of the $\mathrm{C} / \mathrm{N}$ ratio during composting [18]. The $\mathrm{C} / \mathrm{N}$ ratio in all treatments during composting in this experiment decreased from around 34.64 to 25.36 . These results were in accordance with those in another reported by Tiquia et al. [43], in which the decline of the $\mathrm{C} / \mathrm{N}$ ratio from 28 to 17 was reported during the composting of chicken manure.

The ammonification and nitrification processes were also monitored by determining the concentrations of $\mathrm{NH}_{4}^{+}$and $\mathrm{NO}_{3}^{-}$. The ammonification reaction is indicated by the release of $\mathrm{NH}_{4}^{+}$, while nitrification is indicated by the production of $\mathrm{NO}_{3}^{-}$[55]. The $\mathrm{NH}_{4}^{+}$variation throughout the 
composting process is shown in Figure $4 \mathrm{D}$. The $\mathrm{NH}_{4}^{+}$content in all treatments decreased gradually during composting. We observed the $\mathrm{NH}_{4}-\mathrm{N}$ decrease rapidly only in the treatments of composting with biochar (BC and BC-I) either by continuous and intermittent aeration (Figure 4D). Reduction of the ammonification rate could be attributed to the alkalinity and high absorptive capacity of the biochar [31,40]. Chen et al. [60] reported that the application of alkaline biochar with a high absorptive capacity played a major role in maintaining the soil $\mathrm{pH}$, enhanced the adsorption of $\mathrm{NH}_{4}^{+} / \mathrm{NH}_{3}$, and thereby reduced the $\mathrm{NH}_{3}$ volatilization.

The treatment with Co-additives and continuous aeration showed a rapid decrease of $\mathrm{NH}_{4}^{+}$. In biochar additive treatment, $\mathrm{NH}_{4}^{+}$decreased rapidly after the second week of composting while other treatments showed rapid decreases after the third week of composting (Figure 4D). The increase of $\mathrm{NH}_{4}^{+}$during the first week of composting could be due to the decomposition of nitrogen-containing organic matter to form ammonia. The decrease of $\mathrm{NH}_{4}^{+}$during composting was attributed to assimilation by microorganisms, to volatilization, and to nitrification [42].
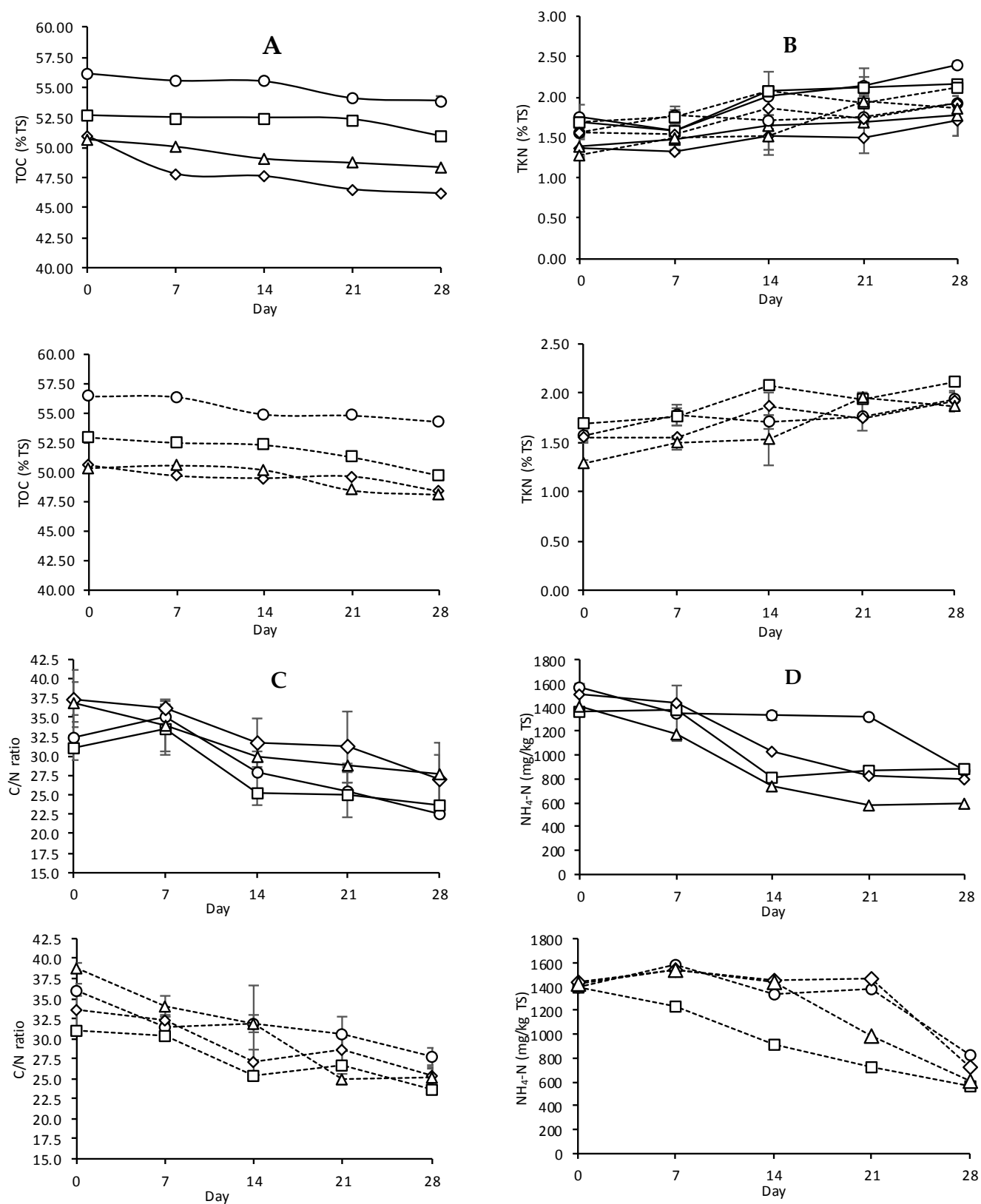

Figure 4. Cont. 

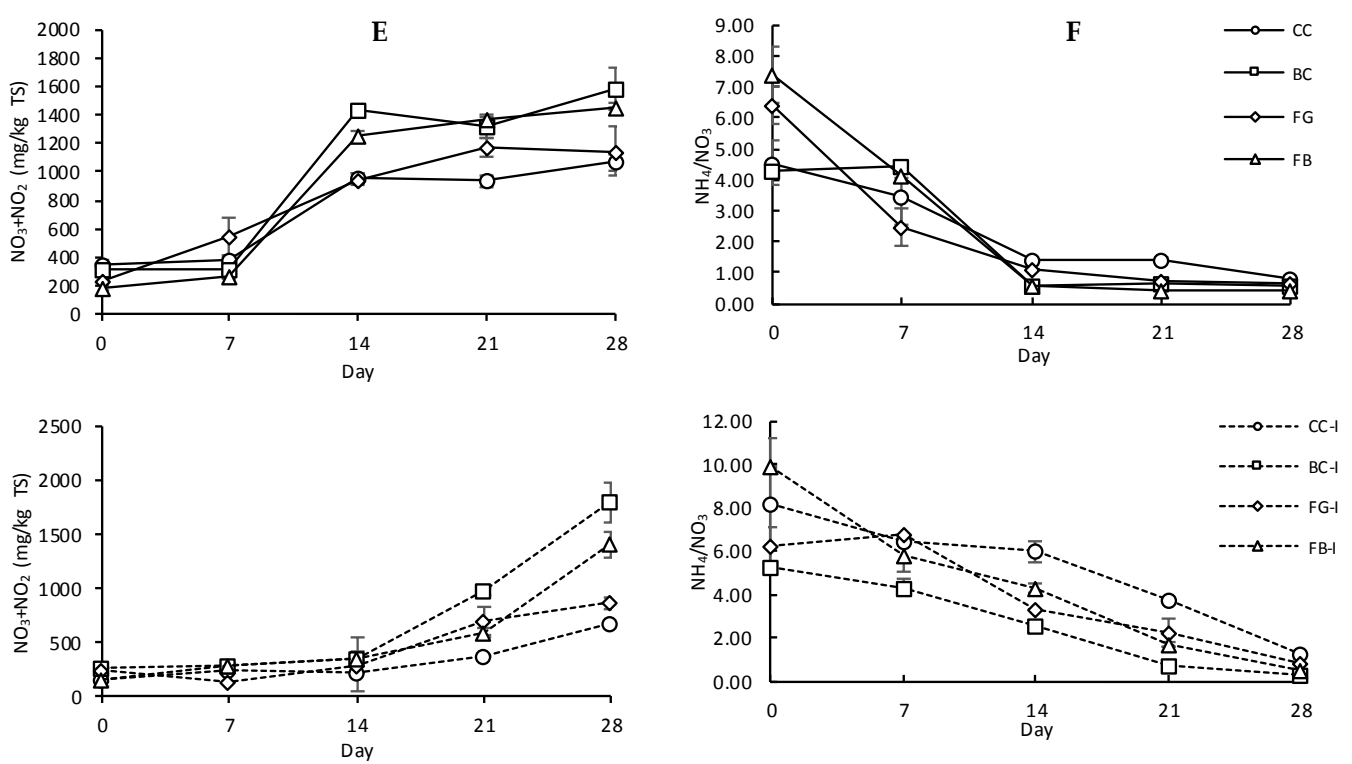

Figure 4. TOC (A); TKN (B); C/N ratio (C); $\mathrm{NH}_{4}-\mathrm{N}(\mathbf{D}) ; \mathrm{NO}_{3}+\mathrm{NO}_{2}(\mathbf{E}) ; \mathrm{NH}_{4} / \mathrm{NO}_{3}$ (F) throughout the composting process.

The $\mathrm{NO}_{3}^{-}+\mathrm{NO}_{2}^{-}$transformation during composting are shown in Figure 4E. Different aeration schemes showed a different pattern of $\mathrm{NO}_{3}^{-}+\mathrm{NO}_{2}^{-}$transformation. In continuous aeration, $\mathrm{NO}_{3}^{-}+\mathrm{NO}_{2}^{-}$accumulation started rapidly from the second week of composting, while rapid $\mathrm{NO}_{3}^{-}+\mathrm{NO}_{2}^{-}$accumulation under intermittent aeration started after three weeks of composting. Late accumulation of $\mathrm{NO}_{3}^{-}+\mathrm{NO}_{2}^{-}$in intermittent aeration treatments could be due to the late activation of nitrifying bacteria. The growth and activity of nitrifying bacteria are inhibited during the temperature conditions of more than $40{ }^{\circ} \mathrm{C}$ [42]. The temperature goes down slowly under intermittent aeration rather than under continuous aeration, thus the condition in which nitrifying bacteria could actively proliferate was delayed. Co-additives treatment of FGD gypsum and biochar (FB and FB-I) showed the highest $\mathrm{NO}_{3}^{-}+\mathrm{NO}_{2}^{-}$accumulation rate (6.72 and 7.90-fold) during the 28 days composting. As the composting progressed to the cooling phase, the autotrophic nitrifying bacteria increased and oxidized $\mathrm{NH}_{4}^{+}$to $\mathrm{NO}_{2}^{-}$, which was further oxidized to $\mathrm{NO}_{3}^{-}$by nitrite-oxidizing microorganisms. During the intermittent aeration treatment, the presence of biochar increased the porosity of the compost pile, which may induce oxygen penetration and accelerate the nitrification or conversion of $\mathrm{NH}_{4}^{+}$to $\mathrm{NO}_{3}^{-}+\mathrm{NO}_{2}^{-}$. Furthermore, absorption via the transfer of $\mathrm{NO}_{3}^{-}$along with soil pore solution into biochar pores could also be possible. The adsorption of $\mathrm{NO}_{3}^{-}$(an anion) to biochar may also be related to its anion exchange capacity [53].

Figure $4 \mathrm{~F}$ shows the $\mathrm{NH}_{4}^{+} / \mathrm{NO}_{3}^{-}$ratio throughout the composting process. The $\mathrm{NH}_{4}^{+} / \mathrm{NO}_{3}^{-}$ ratio is a desirable candidate indicator for compost maturity [30]. The $\mathrm{NH}_{4}^{+} / \mathrm{NO}_{3}^{-}$ratio of all treatments in the present study decreased gradually. The $\mathrm{NH}_{4}^{+} / \mathrm{NO}_{3}^{-}$ratio of FG-I increased in the first week of composting, which could be due to the inhibition of nitrification and accumulation of $\mathrm{NH}_{4}^{+}$. The addition of FGD gypsum increased the soluble salt, as indicated by the higher EC. The high $\mathrm{EC}$ or $\mathrm{pH}$ of the additive might disrupt nitrification by inhibiting the growth of nitrifying bacteria [12,15]. Because the presence of biochar provides benefits that induce nitrifying bacteria growth [47], we observed that biochar might serve to overcome the limitation of adding FGD gypsum alone in composting. We also observed a similar pattern of $\mathrm{NH}_{4}^{+} / \mathrm{NO}_{3}^{-}$. decrease during composting by both continuous and intermittent aeration. 


\subsection{The Effects on Macro-, Micronutrients and Maturity Indices}

The effects of the co-additive treatment and aeration scheme on the concentrations of macroand micro- mineral nutrients are summarized in Tables 3 and 4, respectively. FGD gypsum treatment tends to increase the concentrations of $\mathrm{P}, \mathrm{Ca}, \mathrm{Mg}$, and $\mathrm{S}$ in the compost $(p<0.05)$, whereas compost with biochar had elevated amounts of Fe and $\mathrm{Mn}(p<0.05)$. These high concentrations of minerals can be explained by the nature of the additives and the slaughter waste substrate. In addition, the mineralization process during composting increased the concentration of mineral nutrients. Hu et al. [61] suggested that mature compost should contain a variety of nutrients such as phosphorus $(2.15 \mathrm{~g} / \mathrm{kg})$, potassium $(0.79 \mathrm{~g} / \mathrm{kg})$, calcium $(12.9 \mathrm{~g} / \mathrm{kg})$, magnesium $(8.0 \mathrm{~g} / \mathrm{kg})$, sulphur $(3 \mathrm{~g} / \mathrm{kg})$, sodium $(1.15 \mathrm{~g} / \mathrm{kg})$, iron $(1.2 \mathrm{~g} / \mathrm{kg})$, along with trace amounts of zinc $(24.9 \mathrm{mg} / \mathrm{kg})$, manganese $(80.4 \mathrm{mg} / \mathrm{kg})$, copper $(5.7 \mathrm{mg} / \mathrm{kg})$, and boron $(5.7 \mathrm{mg} / \mathrm{kg})$. The balance of macro and micro nutrients of compost observed in the present study was achieved by the co-additive treatment (combined FGD gypsum and biochar). The compost treated with the co-additive contained no extremely high macroand micro-mineral concentrations. The observed results show that compost aerated by continuous aeration mostly contains comparatively higher macro- and micro-mineral nutrient concentrations. This indicated that a higher rate of mineralization occurred under continuous aeration than under intermittent aeration. The high mineral concentration of the compost could also be the effect of the mineral content in the raw materials (slaughterhouse and pig slurry), which initially contained a high concentration of minerals.

The maturity indices from the composting test are presented in Table 5. The $\mathrm{pH}$ of the compost derived from the present study varied in a range of about 5.50-8.69. The lowest $\mathrm{pH}$ was achieved in FG-I (5.50) while the highest $\mathrm{pH}$ was achieved in BC-I (8.69). These were significantly different $(p<0.05)$ from the controls CC (7.05) and CC-I (6.64). Hogg et al. [62] reported that in most European national standards, compost should have a $\mathrm{pH}$ value within the range of 6.0-8.5 to ensure the safety of most plants. Hu et al. [61] suggested that the mature compost was slightly acidic. Most of the compost in this study was within the safe range limit of $\mathrm{pH}$ except the treatments with only FGD gypsum additive (FG-I) and only the biochar additive (BC-I). The pH of FG-I (5.5) was slightly more acidic, whereas the $\mathrm{pH}$ of BC-I (8.69) was slightly more alkaline. This condition could be attributable to the nature and effect of the additive treatments used in this study. FGD gypsum might induce low $\mathrm{pH}$ while biochar might induce high $\mathrm{pH}$ in the compost product. The acidic compost has potential use for horticultural growing media because of its $\mathrm{pH}$ of 5-6.5, as suggested by Careces et al. [63]. Several elements such as phosphorus, calcium, and magnesium are likely $25-75 \%$ available under acidic conditions, as reported by Hu et al. [61].

The EC varied across the eight observed composting treatments (Table 5). FGD gypsum and biochar (as co-additives) significantly altered the EC concentration of livestock waste during composting $(p<0.05)$. Compost derived from slaughter waste/slurry/sawdust mix with FGD gypsum and biochar supplementation, had a higher EC $(p<0.05)$ (Table 5). The high EC value of treatment FG, FB, FG-I, and FB-I might be attributable to the nature of FGD gypsum, which initially has high EC [64], and the high EC from amendments applied to soils might induce phytotoxic effects in plants. However, the EC of all the compost produced still could be considered as acceptable for nursery production, the limit of which is about $3000 \mu \mathrm{S} / \mathrm{cm}$, as suggested by Careces et al. [63]. The $\mathrm{C} / \mathrm{N}$ ratios in the product from all the compost treatments are shown in Table 5. Different additive and aeration schemes did not have a significant effect on the $\mathrm{C} / \mathrm{N}$ ratio of the compost produced in this study. The compost produced in the present study had a higher $\mathrm{C} / \mathrm{N}$ ratio than that established by Hu et al. [61] of about 14.6, and by Hogg et al. [62] $(<25)$. 
Table 3. Concentration of macronutrients-after 28 days composting in this experiment.

\begin{tabular}{cccccc}
\hline \multirow{2}{*}{ Treatment } & $\mathbf{P}$ & $\mathbf{K}$ & $\mathbf{N a}$ & $\mathbf{C a}$ & $\mathbf{M g}$ \\
\cline { 2 - 6 } & \multicolumn{5}{c}{$\mathbf{( m g / k g )}$} \\
\hline CC & $494.99 \pm 1.27$ & $3125.03 \pm 38.09$ & $429.66 \pm 5.40$ & $3853.11 \pm 7.22$ & $269.12 \pm 3.55$ \\
BC & $434.28 \pm 1.11$ & $3203.257 \pm 7.78$ & $321.92 \pm 1.51$ & $11,075.89 \pm 19.03$ & $443.36 \pm 2.94$ \\
FG & $470.12 \pm 0.85$ & $2939.59 \pm 13.09$ & $302.94 \pm 2.60$ & $26,624.35 \pm 71.91$ & $694.01 \pm 7.79$ \\
FB & $513.54 \pm 0.68$ & $3634.01 \pm 22.32$ & $399.04 \pm 1.73$ & $26,113.85 \pm 86.57$ & $602.85 \pm 3.47$ \\
CC-I & $651.69 \pm 0.64$ & $1674.51 \pm 19.13$ & $251.23 \pm 2.71$ & $2261.39 \pm 3.62$ & $301.69 \pm 1.79$ \\
BC-I & $461.12 \pm 0.61 \mathrm{~b}$ & $1991.08 \pm 12.28$ & $244.98 \pm 1.06$ & $6685.14 \pm 22.16$ & $306.98 \pm 1.76$ \\
FG-I & $386.95 \pm 35.66$ & $1787.36 \pm 9.07$ & $381.61 \pm 8.14$ & $14,448.42 \pm 209.08$ & $434.25 \pm 2.50$ \\
FB-I & $650.15 \pm 0.79$ & $1679.82 \pm 10.42$ & $313.78 \pm 1.36$ & $11,123.09 \pm 36.87$ & $328.59 \pm 0.82$ \\
\hline
\end{tabular}

Table 4. Concentration of micronutrients-after 28 days composting in this experiment.

\begin{tabular}{cccccc}
\hline \multirow{2}{*}{ Treatment } & Fe & Mn & Cu & Zn & S \\
\cline { 2 - 6 } & \multicolumn{5}{c}{$\mathbf{( m g / k g )}$} \\
\hline CC & $225.37 \pm 0.55$ & $53.07 \pm 1.54$ & $21.16 \pm 0.27$ & $51.98 \pm 0.17$ & $973.46 \pm 2.91$ \\
BC & $628.39 \pm 0.57$ & $147.24 \pm 3.34$ & $19.37 \pm 0.09$ & $36.67 \pm 0.07$ & $1580.28 \pm 3.41$ \\
FG & $460.48 \pm 1.79$ & $46.57 \pm 1.90$ & $15.01 \pm 0.15$ & $38.09 \pm 0.06$ & $14,420.03 \pm 36.23$ \\
FB & $629.88 \pm 1.01$ & $119.09 \pm 4.32$ & $19.45 \pm 0.11$ & $52.73 \pm 0.10$ & $11,325.19 \pm 36.23$ \\
CC-I & $135.77 \pm 0.27$ & $27.23 \pm 0.77$ & $14.65 \pm 0.13$ & $105.88 \pm 0.17$ & $1500.77 \pm 1.46$ \\
BC-I & $401.44 \pm 0.65$ & $86.61 \pm 3.14$ & $13.70 \pm 0.08$ & $71.41 \pm 0.13$ & $1638.19 \pm 5.24$ \\
FG-I & $192.48 \pm 2.09$ & $21.56 \pm 1.04$ & $8.68 \pm 0.12$ & $69.96 \pm 2.64$ & $10,752.07 \pm 88.65$ \\
FB-I & $330.02 \pm 0.53$ & $54.72 \pm 1.98$ & $13.45 \pm 0.08$ & $120.91 \pm 0.22$ & $6828.30 \pm 21.69$ \\
\hline
\end{tabular}

Table 5. Characteristic of maturity indices from the composting test.

\begin{tabular}{ccccc}
\hline Treatment & $\mathbf{p H}$ & Electrical Conductivity $(\boldsymbol{\mu S} / \mathbf{c m})$ & $\mathbf{C} / \mathbf{N}$ Ratio & Germination Index (\%) \\
\hline CC & $7.05 \pm 0.05$ & $610 \pm 31.11$ & $22.47 \pm 0.22$ & $104.56 \pm 6.88$ \\
BC & $8.25 \pm 0.03$ & $354 \pm 47.38$ & $23.64 \pm 0.13$ & $109.02 \pm 6.30$ \\
FG & $6.06 \pm 0.04$ & $1295 \pm 176.78$ & $27.08 \pm 3.14$ & $139.43 \pm 9.14$ \\
FB & $7.03 \pm 0.11$ & $1405 \pm 190.92$ & $27.69 \pm 3.95$ & $125.89 \pm 2.51$ \\
CC-I & $6.64 \pm 0.13$ & $553 \pm 90.19$ & $27.76 \pm 1.04$ & $117.42 \pm 6.91$ \\
BC-I & $8.69 \pm 0.15$ & $570 \pm 28.28$ & $26.68 \pm 0.49$ & $104.07 \pm 9.28$ \\
FG-I & $5.5 \pm 0.05$ & $1330 \pm 183.85$ & $25.40 \pm 0.95$ & $129.92 \pm 0.99$ \\
FB-I & $5.98 \pm 0.12$ & $1769 \pm 82.73$ & $25.23 \pm 0.98$ & $131.64 \pm 39.22$ \\
\hline
\end{tabular}

\subsection{The Effect on Germination and Respiration Rate}

The germination index of all treatments gradually increased during composting (Figure 5A). The germination index may reflect the toxicity level of the final compost; a low germination index equals to high toxicity contained by the compost, and a high germination index means low toxicity. Because this compost substrate originated from slaughterhouse waste and pig slurry, there is some potential for the presence of toxic substances. The increase of the germination index during composting indicated that the toxicity was decreased. The decline of the toxic level was associated with the decomposition of organic matter and conversion of toxic matter to non-toxic matter. This involved the release of toxic substances (for example, ammonia and low-molecular-weight short chain volatile fatty acids, primarily acetic acid) [65]. We observed from the present study that the co-additive and aeration scheme treatments did not have any significant effect on -the germination index and respiration rate of the composting process.

Figure 5B shows the respiration rate in all the composting treatments. According to the results, the rate of respiration of composting with continuous aeration decreased more rapidly than with intermittent aeration treatments. Low rates of respiration are indicative of highly stabilized compost. It was reported that the final compost has a $\mathrm{CO}_{2}$ respiration rate in a range $0.3-0.6 \mathrm{mg} \mathrm{CO} 2 / \mathrm{g}$ substrate, 
which was reached after 80-90 days of composting [66]. We observed that for the compost products from the present study, the $\mathrm{CO}_{2}$ respiration rate values were in the range of $8.03-13.83 \mathrm{mgCO} / \mathrm{g} \cdot \mathrm{TS}$ after 28 days of composting, which indicated the need for more time to be more stabilized However, the use of co-additives did not have any negative effects on the compost respiration rate.
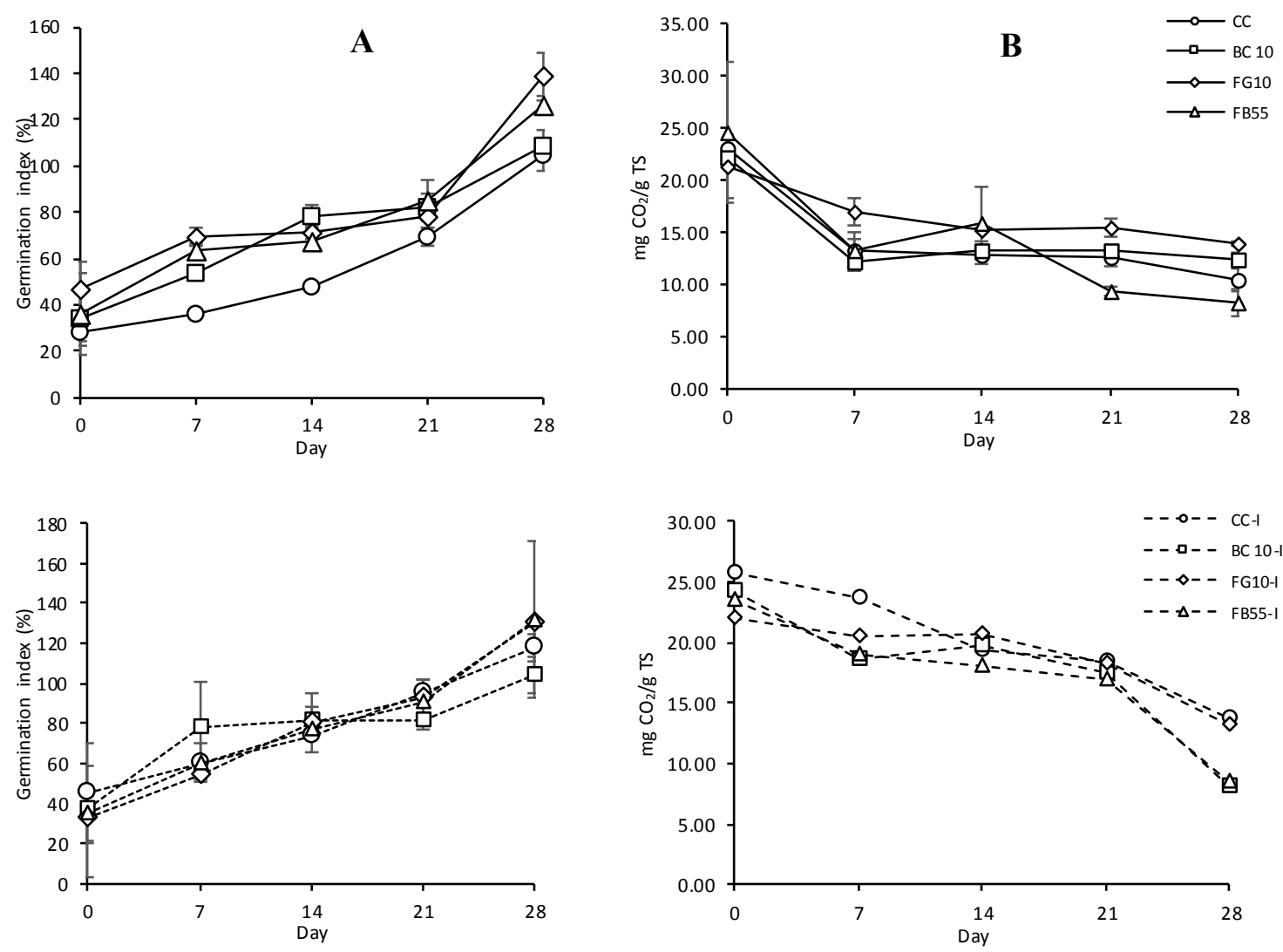

Figure 5. Change in (A) Germination index; (B) $\mathrm{CO}_{2}$ respiration rate during composting.

\section{Conclusions}

According to the results of this study, it can be concluded that co-additives treatment using FGD gypsum and biochar did not give adverse effect during the 28 days livestock waste composting process. The selection of appropriate additives needs to be adjusted for the purpose of composting. FGD gypsum supplementation may reduce ammonia volatilization more than biochar supplementation however biochar supplementation may give a faster biodegradation process during composting, thus co-additive treatment during composting might be an alternative method to reduce ammonia volatilization as well as induce the biodegradation process.

Supplementation of livestock waste composting with the co-additives FGD gypsum and biochar reduced ammonia loss and enhanced nutrient recovery. The utilization of these co-additives led to the reduction of ammonia volatilization by $26-59 \%$ and to an increase in the nitrate $\left(\mathrm{NO}_{3}^{-}\right)$accumulation by 6.7-7.9 fold compare to the initial value. The total ammonia volatilization of the intermittent aeration treatment was lower than that of continuous aeration using co-additive treatments. The macro- and micro-nutrient content were enhanced by the supplementation with these co-additives. The use of co-additives did not have any negative effect on the compost respiration rate and reduced the phytotoxic effect. Some parameter showed that livestock waste composting using co-additives during the 28 days results in waste that is safe to be discharged to the environment, however, the waste will not have matured yet to be utilized as a compost fertilizer. Studies on the co-additive application 
on the pilot and large-scale composting are necessary to investigate the effectiveness and economic visibility of this method.

Acknowledgments: This work was supported by the Korea Institute of Planning and Evaluation for Technology in Food, Agriculture, and Forestry (iPET), project number 116049-3 of the Ministry of Agriculture, Food, and Rural Affairs. The authors also thank the Indonesia Endowment Fund for Education (LPDP) for financial support during this study.

Author Contributions: Andi Febrisiantosa and Hong L. Choi conceived and designed the experiments; Andi Febrisiantosa performed the experiments. Andi Febrisiantosa and Balasubramani Ravindran analyzed the data; Andi Febrisiantosa, Hong L. Choi and Balsubramani Ravindran wrote the paper.

Conflicts of Interest: The authors declare no conflicts of interest.

\section{References}

1. Thornton, P.K. Livestock production: Recent trends, future prospects. Philos. Trans. R. Soc. Lond. B Biol. Sci. 2010, 365, 2853-2867. [CrossRef] [PubMed]

2. Franke-whittle, I.H.; Insam, H. Treatment alternatives of slaughterhouse wastes, and their effect on the inactivation of different pathogens: A review. Crit. Rev. Microbiol. 2013, 39, 139-151. [CrossRef] [PubMed]

3. ten Hoeve, M.; Hutchings, N.J.; Peters, G.M.; Svanström, M.; Jensen, L.S.; Bruun, S. Life cycle assessment of pig slurry treatment technologies for nutrient redistribution in Denmark. J. Environ. Manag. 2014, 132, 60-70. [CrossRef] [PubMed]

4. Gamroth, M. Composting: An Alternative for Livestock Manure Management and Disposal of Dead Animals; Oregon State University Extension: Corvallis, OR, USA, 2012.

5. Sivakumar, K.; Saravana Kumar, V.R.; Jagatheesan, P.N.R.; Viswanathan, K.; Chandrasekaran, D. Seasonal variations in composting process of dead poultry birds. Bioresour. Technol. 2008, 99, 3708-3713. [CrossRef] [PubMed]

6. Bharathy, N.; Sakthivadivu, R.; Sivakumar, K.; Saravanakumar, V.R. Disposal and utilization of broiler slaughter waste by composting. Vet. World 2012, 5, 359-361. [CrossRef]

7. Pan, I.; Dam, B.; Sen, S.K. Composting of common organic wastes using microbial inoculants. 3 Biotech 2012, 2, 127-134. [CrossRef]

8. Blazy, V.; de Guardia, A.; Benoist, J.C.; Daumoin, M.; Lemasle, M.; Wolbert, D.; Barrington, S. Odorous gaseous emissions as influence by process condition for the forced aeration composting of pig slaughterhouse sludge. Waste Manag. 2014, 34, 1125-1138. [CrossRef] [PubMed]

9. Sun, X.; Lu, P.; Jiang, T.; Schuchardt, F.; Li, G. Influence of bulking agents on $\mathrm{CH}_{4}, \mathrm{~N}_{2} \mathrm{O}$, and $\mathrm{NH}_{3}$ emissions during rapid composting of pig manure from the Chinese Ganqinfen system. J. Zhejiang Univ. Sci. B 2014, 15, 353-364. [CrossRef] [PubMed]

10. Colón, J.; Martínez-blanco, J.; Gabarrell, X.; Artola, A.; Sánchez, A.; Rieradevall, J.; Font, X. Environmental assessment of home composting. Resour. Conserv. Recycl. 2010, 54, 893-904. [CrossRef]

11. Beck-Friis, B.; Smårs, S.; Jönsson, H.; Kirchmann, H. SE-Structures and Environment: Gaseous emissions of carbon dioxide, ammonia and nitrous oxide from organic household waste in a compost reactor under different temperature regimes. J. Agric. Eng. Res. 2001, 78, 423-430. [CrossRef]

12. Martins, O.; Dewes, T. Loss of Nitrogenous Compounds during Composting of Animal Wastes. Bioresour. Technol. 1992, 42, 103-111. [CrossRef]

13. Kithome, M.; Paul, J.W.; Bomke, A.A. Reducing nitrogen losses during simulated composting of poultry manure using adsorbents or chemical amendments. J. Environ. Qual. 1999, 28, 194-201. [CrossRef]

14. Zeng, Y.; Guardia, A.D.; Daumoin, M.; Benoist, J. Characterizing the transformation and transfer of nitrogen during the aerobic treatment of organic wastes and digestates. Waste Manag. 2012, 32, 2239-2247. [CrossRef] [PubMed]

15. Barrington, S.; Choini, D.; Trigui, M.; Knight, W. Effect of carbon source on compost nitrogen and carbon losses. Bioresour. Technol. 2002, 83, 189-194. [CrossRef]

16. Gabhane, J.; Prince, S.P.M.; Bidyadhar, R.; Bhilawe, P.; Anand, D.; Vaidya, A.N.; Wate, S.R. Additives aided composting of green waste: Effects on organic matter degradation, compost maturity, and quality of the finished compost. Bioresour. Technol. 2012, 114, 382-388. [CrossRef] [PubMed] 
17. Nissen, L.R.; Lepp, N.W.; Edwards, R. Synthetic zeolites as amendments for sewage sludge-based compost. Chemosphere 2000, 41, 265-269. [CrossRef]

18. Li, R.; Wang, J.J.; Zhang, Z.; Shen, F.; Zhang, G.; Qin, R.; Li, X.; Xiao, R. Nutrient transformations during composting of pig manure with bentonite. Bioresour. Technol. 2012, 121, 362-368. [CrossRef] [PubMed]

19. Huang, G.F.; Wu, Q.T.; Wong, J.W.C.; Nagar, B.B. Transformation of organic matter during co-composting of pig manure with sawdust. Bioresour. Technol. 2006, 97, 1834-1842. [CrossRef] [PubMed]

20. Zhang, J.; Luo, L.; Gao, J.; Peng, Q.; Huang, H.; Chen, A. Ammonia-oxidizing bacterial communities and shaping factors with di ff erent Phanerochaete chrysosporium inoculation regimes during. RSC Adv. 2016, 6, 61473-61481. [CrossRef]

21. Malińska, K.; Zabochnicka-Świątek, M.; Dach, J. Effects of biochar amendment on ammonia emission during composting of sewage sludge. Ecol. Eng. 2014, 71, 474-478. [CrossRef]

22. Vandecasteele, B.; Sinicco, T.; D'Hose, T.; Vanden Nest, T.; Mondini, C. Biochar amendment before or after composting affects compost quality and $\mathrm{N}$ losses, but not P plant uptake. J. Environ. Manag. 2016, 168, 200-209. [CrossRef] [PubMed]

23. Huang, X.-D.; Xue, D. Effects of bamboo biochar addition on temperature rising, dehydration and nitrogen loss during pig manure composting. Chin. J. Appl. Ecol. 2014, 25, 1057-1062.

24. Sánchez-García, M.; Alburquerque, J.A.; Sánchez-Monedero, M.A.; Roig, A.; Cayuela, M.L. Biochar accelerates organic matter degradation and enhances $\mathrm{N}$ mineralisation during composting of poultry manure without a relevant impact on gas emissions. Bioresour. Technol. 2015, 192, 272-279. [CrossRef] [PubMed]

25. Yoshizawa, S.; Tanaka, S.; Ohata, M.; Mineki, S.; Goto, S.; Fujioka, K.; Kokubun, T. Promotion effect of various charcoals on the proliferation of composting microorganisms. Tanso 2006, 224, 261-265. [CrossRef]

26. Jindo, K.; Suto, K.; Matsumoto, K.; García, C.; Sonoki, T.; Sanchez-Monedero, M.A. Chemical and biochemical characterisation of biochar-blended composts prepared from poultry manure. Bioresour. Technol. 2012, 110, 396-404. [CrossRef] [PubMed]

27. Mayer, P.; Hilber, I.; Gouliarmou, V.; Hale, S.E.; Cornelissen, G.; Bucheli, T.D. How to Determine the Environmental Exposure of PAHs Originating from Biochar. Environ. Sci. Technol. 2016, 50, 1941-1948. [CrossRef] [PubMed]

28. Guo, X.; Lu, Y.; Li, Q. Effect of adding flue gas desulphurization gypsum on the transformation and fate of nitrogen during composting. Compost Sci. Util. 2016, 24, 230-237. [CrossRef]

29. Tubail, K.; Chen, L.; Michel, F.C.; Keener, H.M.; Rigot, J.F.; Klingman, M.; Kost, D.; Dick, W.A. Gypsum Additions Reduce Ammonia Nitrogen Losses During Composting of Dairy Manure and Biosolids. Compost Sci. Util. 2008, 16, 285-293. [CrossRef]

30. Guo, X.; Huang, J.; Lu, Y.; Shan, G.; Li, Q. The influence of flue gas desulphurization gypsum additive on characteristics and evolution of humic substance during co-composting of dairy manure and sugarcane pressmud. Bioresour. Technol. 2016, 219, 169-174. [CrossRef] [PubMed]

31. Chen, Q.; Wang, S.; Li, Y.; Zhang, N.; Zhao, B.; Zhuo, Y.; Chen, C. Influence of Flue Gas Desulfurization Gypsum Amendments on Heavy Metal Distribution in Reclaimed Sodic Soils. Environ. Eng. Sci. 2015, 32, 470-478. [CrossRef] [PubMed]

32. Presley, D. Effects of Flue Gas Desulfurization Gypsum on Crop Yield and Soil Properties in Kansas. Kansas Agric. Exp. Stn. Res. Rep. 2016, 2. [CrossRef]

33. Ahn, H.K.; Richard, T.L.; Choi, H.L. Mass and thermal balance during composting of a poultry manure-Wood shavings mixture at different aeration rates. Process Biochem. 2007, 42, 215-223. [CrossRef]

34. Lu, S.G.; Imai, T.; Li, H.F.; Ukita, M.; Sekine, M.; Higuchi, T. Effect of enforced aeration on in-vessel food waste composting. Environ. Technol. 2001, 22, 1177-1182. [CrossRef] [PubMed]

35. APHA. Standard Methods for the Examination of Water and Wastewater, 9th ed.; American Public Health Association: Washington, DC, USA, 2005.

36. Thompson, W.H.; Millner, P.D.; Watson, M.E.; Leege, P.B. Test Methods for the Examination of Composting and Compost (TMECC); USCC (United States Composting Council): Holbrook, NY, USA, 2002.

37. Bremmer, J.M.; Sparks, D.L.; Page, A.L.; Helmke, P.A.; Leoppert, R.H.; Soltanpour, P.N.; Tabatabai, M.A.; Johnston, C.T.; Sumner, M.E. Nitrogen-Total. In Methods of Soil Analysis, Part 3-Chemical Methods; Bigham, J.M., Ed.; SSSA Book Series 5; ASA: Madison, WI, USA, 1996. 
38. Nelson, D.W.; Sommers, L.E. Total Carbon, Organic Carbon and Organic Matter. In Methods of Soil Analysis Part 3-Chemical Methods; Sparks, D.L., Ed.; SSSA Book Series5; ASA: Madison, WI, USA, 1996; pp. 961-1010.

39. Ren, L.; Schuchardt, F.; Shen, Y.; Li, G.; Li, C. Impact of struvite crystallization on nitrogen losses during composting of pig manure and cornstalk. Waste Manag. 2010, 30, 885-892. [CrossRef] [PubMed]

40. Sellami, F.; Hachicha, S.; Chtourou, M.; Medhioub, K.; Ammar, E. Maturity assessment of composted olive mill wastes using UV spectra and humification parameters. Bioresour. Technol. 2008, 99, 6900-6907. [CrossRef] [PubMed]

41. Bustamante, M.A.; Paredes, C.; Marhuenda-Egea, F.C.; Pérez-Espinosa, A.; Bernal, M.P.; Moral, R. Co-composting of distillery wastes with animal manures: Carbon and nitrogen transformations in the evaluation of compost stability. Chemosphere 2008, 72, 551-557. [CrossRef] [PubMed]

42. Gao, M.; Li, B.; Yu, A.; Liang, F.; Yang, L.; Sun, Y. The effect of aeration rate on forced-aeration composting of chicken manure and sawdust. Bioresour. Technol. 2010, 101, 1899-1903. [CrossRef] [PubMed]

43. Tiquia, S.M.; Wan, H.C.; Tam, N.F.Y. Microbial population dynamics and enzyme activities during composting. Compost Sci. Util. 2002, 10, 150-161. [CrossRef]

44. Jiang, T.; Schuchardt, F.; Li, G.; Guo, R.; Zhao, Y. Effect of C/N ratio, aeration rate and moisture content on ammonia and greenhouse gas emission during the composting. J. Environ. Sci. 2011, 23, 1754-1760. [CrossRef]

45. Canadian Council of Ministers of the Environment (CCME). CCME Guidelines for Compost Quality; CCME: Ottawa, ON, Canada, 2005; ISBN 1-896997-60-0.

46. López-Cano, I.; Roig, A.; Cayuela, M.L.; Alburquerque, J.A.; Sánchez-Monedero, M.A. Biochar improves $\mathrm{N}$ cycling during composting of olive mill wastes and sheep manure. Waste Manag. 2016, 49, 553-559. [CrossRef] [PubMed]

47. Liu, W.; Huo, R.; Xu, J.; Liang, S.; Li, J.; Zhao, T.; Wang, S. Effects of biochar on nitrogen transformation and heavy metals in sludge composting. Bioresour. Technol. 2017, 235, 43-49. [CrossRef] [PubMed]

48. Du, S.; Chen, X.; Hou, M. Study on the desalination process and improvement effect of FGD-gypsum improving coastal saline-soil. In IOP Conference Series: Earth and Environmental Science; IOP Publishing: Bristol, UK, 2017; Volume 59, pp. 1-7.

49. Tiquia, S.M.; Tam, N.F.Y. Fate of nitrogen during composting of chicken litter. Environ. Pollut. 2000, 110, 535-541. [CrossRef]

50. Pagans, E.; Barrena, R.; Font, X.; Sánchez, A. Ammonia emissions from the composting of different organic wastes. Dependency on process temperature. Chemosphere 2006, 62, 1534-1542. [CrossRef] [PubMed]

51. Koenig, R.T.; Palmer, M.D.; Miner, F.D.; Miller, B.E.; Harrison, J.D. Chemical Amendments and Process Controls To Reduce Ammonia Volatilization During In-House Composting. Compost Sci. Util. 2005, 13, 141-149. [CrossRef]

52. Jeong, Y.K.; Kim, J.S. A new method for conservation of nitrogen in aerobic composting processes. Bioresour. Technol. 2001, 79, 129-133. [CrossRef]

53. Khan, N.; Clark, I.; Sánchez-Monedero, M.A.; Shea, S.; Meier, S.; Bolan, N. Maturity indices in co-composting of chicken manure and sawdust with biochar. Bioresour. Technol. 2014, 168, 245-251. [CrossRef] [PubMed]

54. Schomberg, H.H.; Gaskin, J.W.; Harris, K.; Das, K.C.; Novak, J.M.; Busscher, W.J.; Watts, D.W.; Woodroof, R.H.; Lima, I.M.; Ahmedna, M.; et al. Influence of Biochar on Nitrogen Fractions in a Coastal Plain Soil. J. Environ. Qual. 2012, 41, 1087-1095. [CrossRef] [PubMed]

55. Mandal, S.; Thangarajan, R.; Bolan, N.S.; Sarkar, B.; Khan, N.; Ok, Y.S.; Naidu, R. Biochar-induced concomitant decrease in ammonia volatilization and increase in nitrogen use efficiency by wheat. Chemosphere 2016, 142, 120-127. [CrossRef] [PubMed]

56. Bolan, N.S.; Saggar, S.; Luo, J.; Bhandral, R.; Singh, J. Gaseous emissions of nitrogen from grazed pastures: Processes, measurements and modelling, environmental implications, and mitigation. Adv. Agron. 2004, 84. [CrossRef]

57. Liang, Y.; Leonard, J.J.; Feddes, J.J.R.; McGill, W.B. Influence of carbon and buffer amendment on ammonia volatilization in composting. Bioresour. Technol. 2006, 97, 748-761. [CrossRef] [PubMed]

58. Canfield, D.E.; Glazer, A.N.; Falkowski, P.G. The evolution and future of earth's nitrogen cycle. Science 2010, 330, 192-196. [CrossRef] [PubMed] 
59. de Guardia, A.; Mallard, P.; Teglia, C.; Marin, A.; Le Pape, C.; Launay, M.; Benoist, J.C.; Petiot, C. Comparison of five organic wastes regarding their behaviour during composting: Part 2, nitrogen dynamic. Waste Manag. 2010, 30, 415-425. [CrossRef] [PubMed]

60. Chen, C.R.; Phillips, I.R.; Condron, L.M.; Goloran, J.; Xu, Z.H.; Chan, K.Y. Impacts of greenwaste biochar on ammonia volatilisation from bauxite processing residue sand. Plant Soil 2013, 367, 301-312. [CrossRef]

61. Hu, Z.; Lane, R.; Wen, Z. Composting clam processing wastes in a laboratory- and pilot-scale in-vessel system. Waste Manag. 2009, 29, 180-185. [CrossRef] [PubMed]

62. Hogg, D.; Barth, J.; Favoino, E.; Centemero, M.; Caimi, V.; Amlinger, F.; Devliegher, W.; Brinton, W.; Antler, S. Comparison of Compost Standards Within the EU, North America and Australasia; The Waste and Resources Action Programme: Banbury, Oxon, UK, 2002; ISBN 1844050033.

63. Careces, R.; Flotats, X.; Marfa, O. Changes in the chemical and physicochemical properties of the solid fraction of cattle slurry during composting using different aeration strategies. Waste Manag. 2006, 26, 1081-1091. [CrossRef] [PubMed]

64. Liu, K.; Price, G.W. Evaluation of three composting systems for the management of spent coffee grounds. Bioresour. Technol. 2011, 102, 7966-7974. [CrossRef] [PubMed]

65. Gopinathan, M.; Thirumurthy, M. Evaluation of Phytotoxicity for Compost from Organic Fraction of Municipal Solid Waste and Paper \& Pulp Mill Sludge. Environ. Res. Eng. Manag. 2012, 1, 47-51.

66. Wang, P.; Changa, C.M.; Watson, M.E.; Dick, W.A.; Chen, Y.; Hoitink, H.A.J. Maturity indices for composted dairy and pig manures. Soil Biol. Biochem. 2004, 36, 767-776. [CrossRef]

(C) 2018 by the authors. Licensee MDPI, Basel, Switzerland. This article is an open access article distributed under the terms and conditions of the Creative Commons Attribution (CC BY) license (http:/ / creativecommons.org/licenses/by/4.0/). 